\title{
Emission and performance analysis of a diesel engine burning cashew nut shell oil bio diesel mixed with hexanol
}

\author{
Amith Kishore Pandian ${ }^{1} \cdot$ Dinesh Babu Munuswamy ${ }^{2} \cdot$ Santhanakrishnan Radhakrishanan $^{3} \cdot$ Yuvarajan Devarajan $^{4}$. \\ Ramesh Bapu Bathey Ramakrishnan ${ }^{5}$ Beemkumar Nagappan ${ }^{1}$
}

Received: 3 March 2017 / Published online: 5 January 2018

(c) The Author(s) 2018. This article is an open access publication

\begin{abstract}
In this study, the effect of doping hexanol into biodiesel which is from neat cashew nut shell biodiesel oil on the emissions and the performance characteristics was studied in a constant speed diesel engine. The main purpose of this work is to reduce various emissions and also to improve the performance of the diesel engine when fueled with blends of hexanol and neat cashew nut shell biodiesel. Cashew nut shell oil is not edible, and hence it can be used as a viable alternative to diesel. Cashew nut shell biodiesel is prepared by conventional transesterification. Hexanol with $99.2 \%$ purity was employed as an oxygenated additive. Experimental studies were conducted by fueling diesel as a baseline and by fueling hexanol and neat cashew nut shell biodiesel mixture. A fuel comprising 10\% (by volume) of hexanol and $90 \%$ (by volume) neat cashew nut shell biodiesel was referred to as CNSBD900H100 and fuel comprising 20\% (by volume) of hexanol and 80\% (by volume) of neat cashew nut shell biodiesel was referred to as CNSBD800H200. This study also investigated the possibility of using pure biofuel in an unmodified naturally aspirated diesel engine. The outcome of this study showed that adding hexanol at $10 \%$ and $20 \%$ (by volume) to cashew nut shell biodiesel results in a reduction in emissions. In addition, a significant improvement in brake thermal efficiency and reduction in brake-specific fuel consumptions were achieved. Hence, it could be concluded that hexanol could be a viable and promising additive for improving the drawbacks of biodiesel when it was used to fuel an unmodified diesel engine.
\end{abstract}

Keywords Hexanol $\cdot$ Biodiesel $\cdot$ Engine performance $\cdot$ Emission

\section{Introduction}

There is concern that availability of crude oil and petroleum products may decline in the future and that they will also continue to be expensive. On the other hand, the fuel economy of engines is improving and will continue to

Edited by Xiu-Qin Zhu

Amith Kishore Pandian

amithkishore.mech@sathyabamauniversity.ac.in

1 Department of Mechanical Engineering, Sathyabama University, Chennai, India

2 Department of Mechanical Engineering, Panimalar Engineering College, Chennai, India

3 Department of Mechanical Engineering, SRM University, Kattankulathur, Chennai, India

4 Department of Mechanical Engineering, Vel Tech Dr. RR \& Dr. SR University, Chennai, India

5 Department of Mechanical Engineering, Chennai Institute of Technology, Chennai, India progress. However, the massive increase in the number vehicles has led to high fuel demand. Gasoline and diesel fuels may probably become limited and costly in the near future. An alternate fuel must be developed to reduce the forecast gap between the demand and the availability of fuel. Biofuels derived from vegetable oils are found to be the most promising alternative fuel to diesel. Biofuels can be employed in existing diesel engines with minor or no modifications (Mohod et al. 2015). In addition, the use of biofuel can extend the life of diesel engines because it is more lubricating than petroleum diesel fuel (Mohod et al. 2011). However, studying the behavior of biofuel as a neat fuel is an inevitable task for designing the combustion 
process of the future's engines. The chemical composition of these biofuels should also be studied in order to use them as a prospective alternate fuel for future application in engines and combustors. The recent scenario suggests that about $88 \%$ of the global energy consumption is from fossil fuels (Mohod et al. 2008, 2011). On the other hand, fossil reserves are predicted to become depleted in the future.

Among the biofuels like biogas, bioalcohol, and biodiesel, alcohol seems to be most common. Biogas requires high pressure for its use in automobile, and its leakage can be hazardous (Rakopoulos et al. 2010a). Biodiesel from edible vegetable oil can cause a shortage in the food supply. Non-edible oil sources require large-scale cultivation which can take up the land resources meant for food crops. Alcohols can be obtained by anaerobic fermentation of lignocellulosic biomass which includes agricultural waste biomass (rice straw, cornstalks, and sugarcane bagasse), forestry biomass (wood-pulp, saw-mill, and paper-mill discards) without much reliance on food crops (Rakopoulos et al. 2011). Further energy crops like switchgrass (Panicum virgatum) and elephant grass can produce a high yield of lignocellulosic biomass that can serve as raw materials for alcohol production. Hence, availability of alcohols would not be an issue.

Ethanol and butanol are suitable for gasoline engines and can be used as octane improvers since their low relative reactivity at low temperatures suppresses uncontrolled auto-ignition (Rakopoulos et al. 2010b). While auto-ignition should be avoided in gasoline engines, it is necessary for diesel engines and for modern engines. Thus, new fuels with high reactivity at low temperatures are required to achieve the overall aim of reducing the world's dependency on conventional fossil fuels and reducing greenhouse gas emissions.

Hexanol is an alcohol with six carbon atoms in the parent chain. It is a colorless liquid, slightly soluble in water, but miscible with diethyl ether and ethanol. Two additional straight-chain isomers of 1-hexanol, 2-hexanol, and 3-hexanol exist, both of which differing by the location of the hydroxyl group (Karabektas and Hosoz 2009; Murcak et al. 2013; Campos-Fernandez et al. 2013). Many isomeric alcohols have the formula $\mathrm{C}_{6} \mathrm{H}_{13} \mathrm{OH}$. It is used in the perfume industry. The present study explores the possibility of using hexanol as a blend component with neat diesel by up to $20 \%$ by volume. Blending of oxygenated alcohols like hexanol with biodiesel will populate fuel-rich regions with hydroxyl group radicals that can catalyze unsaturated HC (hydrocarbon) species to be oxidized rather than participate in soot growth reactions (Murcak et al. 2015; Park et al. 2011).

The other possible reason for choosing hexanol as an alcohol is that hexanol is a 6-carbon straight-chain alcohol that has great potential as a blending component with diesel fuel owing to its higher energy density, higher cetane number, better blend stability and less hygroscopic nature than other widely studied lower alcohols like ethanol, methanol, and even butanol (De Poures et al. 2017). The latent heat of vaporization, density, and viscosity of hexanol is also closer to that of diesel fuel compared to other alcohols (De Poures et al. 2017).

This study paves a way on blending hexanol in neat biodiesel derived from cashew nut shell oil to view its effects on emission characteristics. This study employed four fuels namely, neat diesel, neat cashew nut shell biodiesel, fuel comprising $10 \%$ (by volume) of hexanol and $90 \%$ (by volume) of neat cashew nut shell biodiesel and fuel comprising $20 \%$ of hexanol and $80 \%$ of neat cashew nut shell biodiesel in a constant speed compression ignition engine. The emission and performance characteristics of all the test fuels were investigated and compared with the baseline diesel at ambient conditions.

\section{Experimental materials and methods}

\subsection{Cashew nut shell oil}

The cashew nutshell is about $0.3 \mathrm{~cm}$ thickness with a soft honeycomb structure. Cashew nut shell consists of three layers namely the endocarp, epicarp, and mesocarp. The mesocarp consists of natural resin which holds the shell oil. Cashew nut shell contains a dark reddish brown viscous liquid termed cashew nut shell liquid oil. Cashew nuts shells are a possible feedstock for biodiesel production. Oil extracted from the shell coat and the nut is referred to as cashew nut shell oil (CNSO). The shells of nuts from cashews are dried to reduce the moisture content. They are then milled for higher content of oil. Cashew nut shell oil contains $10 \%$ of cardol and $90 \%$ of anacardic acid (Mohod et al. 2011). The demand of cashew nut shell oil was found to be 10,000 tonnes. The expected growth pace in demand is $7 \%-8 \%$ per annum (Mohod et al. 2008). Fatty acid composition of biodiesel is shown in Table 1 .

Table 1 Fatty acid compositions of biodiesel

\begin{tabular}{ll}
\hline Fatty acids & Cashew nut shell methyl ester, vol\% \\
\hline Palmitic C16:0 & 12.5 \\
Stearic C18:0 & 6.6 \\
Oleic C18:1 & 28.9 \\
Linoleic C18:2 & 35.5 \\
Linoleic C18:3 & 16.5 \\
\hline
\end{tabular}




\subsection{Hexanol}

Hexanol is a higher organic alcohol with a six-carbon chain and has a structural formula of $\mathrm{CH}_{3}\left(\mathrm{CH}_{2}\right)_{5} \mathrm{OH}$. Hexanol is a renewable feedstock obtained from glucose and lignocellulosic biomass by means of engineered micro-organisms like Clostridium species (De Poures et al. 2017). Hexanol is obtained by anaerobic fermentation of lignocellulosic biomass such as rice straw, corn stalks and sugarcane bagasse, wood-pulp, saw-mill and paper-mill discards without much reliance on food crops. Further energy crops like switch grass (Panicum virgatum) and elephant grass can produce a high yield of lignocellulosic biomass that can serve as raw materials for hexanol production. Hexanol is slightly soluble in water but miscible with diethyl ether and ethanol. Two additional straightchain isomers of 1-hexanol, 2-hexanol, and 3-hexanol exist, both of which differing by the location of the hydroxyl group (De Poures et al. 2017). For this study, analytical grade hexanol containing the maximum limits of impurities of cyclohexanone (1.1 vol\%), water $(0.3 \mathrm{vol} \%)$ and the rest being traces of other foreign alcohols. Table 2 shows the properties of hexanol employed in this study.

\subsection{Transesterification process}

Cashew nut shell oil was converted into cashew nut shell biodiesel by conventional transesterification at three different stages.

\subsubsection{Acid-catalyzed esterification process}

A methanolic solution comprised of $95 \mathrm{~mL}$ of methyl alcohol and $5 \mathrm{~mL}$ of sulfuric acid was added at a molar

Table 2 Properties of hexanol (molecular formula, $\mathrm{C}_{6} \mathrm{H}_{13}-\mathrm{OH}$ ). Source Merck Millipore, India

\begin{tabular}{ll}
\hline Properties & Value \\
\hline Molecular weight, $\mathrm{kg} / \mathrm{kmol}$ & 102.18 \\
$\mathrm{C}, \mathrm{wt} \%$ & 70.52 \\
$\mathrm{H}, \mathrm{wt} \%$ & 13.70 \\
$\mathrm{O}, \mathrm{wt} \%$ & 15.70 \\
Cetane number & 23 \\
Self-ignition temperature, ${ }^{\circ} \mathrm{C}$ & 285 \\
Density at $15^{\circ} \mathrm{C}, \mathrm{kg} / \mathrm{m}^{3}$ & 821.8 \\
Viscosity at $40{ }^{\circ} \mathrm{C}, \mathrm{mm} / \mathrm{s}^{2}$ & 3.92 \\
Lower heating value, $\mathrm{MJ} / \mathrm{kg}$ & 39.10 \\
Latent heat of evaporation, $\mathrm{kJ} / \mathrm{kg}$ & 486 \\
Vapor pressure, $\mathrm{mmHg}$ & 1 \\
Boiling point, ${ }^{\circ} \mathrm{C}$ & 157 \\
Flashpoint, ${ }^{\circ} \mathrm{C}$ & 59 \\
\hline
\end{tabular}

ratio of 1:16 to the cashew nut shell oil. This sample was then heated and maintained at a constant temperature of $60{ }^{\circ} \mathrm{C}$ for four different time durations $(30,45,60$ and $90 \mathrm{~min}$ ) under constant stirring with a magnetic stirrer with a hot plate. Based on the result, it was found that heating the mixture at a temperature below $60{ }^{\circ} \mathrm{C}$ for 45 min was the optimum operating condition for the acid-catalyzed esterification process.

\subsubsection{Alkali catalyzed transesterification process}

The transesterification process was continued using sodium hydroxide alkali catalyst. The use of sodium hydroxide was to reduce the free fatty acid content presented in the cashew nut shell oil. In the second stage, the heated cashew nut shell oil was mixed with sodium hydroxide. This process was carried out at different molar ratios and time durations. The optimum conditions for the alkali transesterification process were found to be: oil to methanol molar ratio of 6:1, concentration of sodium hydroxide of $1 \mathrm{wt} \%$, reaction temperature of $60{ }^{\circ} \mathrm{C}$ and reaction time of $45 \mathrm{~min}$ while stirring. Through this process, biodiesel was produced from the reaction between vegetable oil and an alcohol with the aid of strong alkyl catalyst.

\subsubsection{Purification of the oil}

The obtained oil from the alkali transesterification process consisted of cashew nut shell esters and methanol. In the purification process, the methanol dissolved in the oil was removed from cashew nut shell esters to improve the yield of esters. During this process, the transesterified oil was heated at $80{ }^{\circ} \mathrm{C}$ obtaining a yield of $90 \%$ cashew nut shell oil biodiesel. The properties of tested fuels are listed in Table 3.

\subsection{Test engine setup}

A $4.2 \mathrm{~kW}$ single-cylinder, four-stroke air-cooled diesel engine having a compression ratio of 17 was employed in this study. The engine specification is listed in Table 4 . The engine exhaust gases such as $\mathrm{NO}, \mathrm{CO}$ and hydrocarbons (HC) were measured with the aid of an AVL-444 Di gas analyzer and measured at $300 \mathrm{~mm}$ from the exhaust valve. A chemiluminescence detector was employed for detecting $\mathrm{NO}$ emission. It produces a linear and equi-molar response to nitrogen compounds by using a stainless steel burner to achieve high-temperature combustion of nitrogen containing compounds to form nitric oxide (NO). A flame ionization detector analyzer was used to detect $\mathrm{HC}$ emissions detecting ions formed in the combustion of organic compounds in a sample, producing charged molecules that cause electrical conduction between two electrodes. The 
Table 3 Properties of tested fuels

\begin{tabular}{|c|c|c|c|c|c|}
\hline Properties & CNSBD & CNSBD900H100 & CNSBD800H200 & Diesel & Method \\
\hline Water content, wt $\%$ & 0.11 & 0.10 & 0.10 & 0.001 & ASTM D2709 \\
\hline Density at $18{ }^{\circ} \mathrm{C}, \mathrm{gm} / \mathrm{cc}$ & 0.8833 & 0.8541 & 0.8682 & 0.8210 & ASTM D4052 \\
\hline Kinematic viscosity at $35^{\circ} \mathrm{C}, \mathrm{mm}^{2} / \mathrm{s}$ & 4.30 & 4.18 & 4.12 & 2.5 & ASTM D445 \\
\hline Calorific value, $\mathrm{kJ} / \mathrm{kg}$ & 38,108 & 38,884 & 38,912 & 42,950 & ASTM D240 \\
\hline Cetane index (CI) & 52 & 50 & 48 & 46 & ASTM D976 \\
\hline Flash point, ${ }^{\circ} \mathrm{C}$ & 140 & 120 & 111 & 50 & ASTM D93 \\
\hline Iodine value, $\mathrm{g} / 100 \mathrm{~g}$-oil sample & 65 & 65 & 64 & - & ASTM D1510 \\
\hline $\mathrm{C}, \mathrm{wt} \%$ & 77.2 & 78.2 & 75 & - & ASTM D5291 \\
\hline $\mathrm{H}, \mathrm{wt} \%$ & 11.4 & 10.8 & 12 & - & ASTM D5291 \\
\hline $\mathrm{O}, \mathrm{wt} \%$ & 11.4 & 11 & 13 & - & - \\
\hline
\end{tabular}

Table 4 Specification of experimental setup made by Kirloskar oil engine Ltd. (Khadki, Pune, Maharashtra, India)

\begin{tabular}{ll}
\hline Specification & Value \\
\hline Stroke & 4 \\
Cylinder & Single \\
Rated power & $4.2 \mathrm{~kW}$ \\
Rated speed & $1300 \mathrm{rpm}$ \\
Bore diameter $(D)$ & $87.5 \mathrm{~mm}$ \\
Stroke $(L)$ & $110 \mathrm{~mm}$ \\
Compression ratio & $17: 1$ \\
\hline
\end{tabular}

ions are attracted to a collector plate and induce a current upon hitting the plate and the non-dispersive infrared analyzer was used for detecting $\mathrm{CO}$ emissions. Each constituent gas in a sample will absorb some infrared at a particular frequency. By shining an infrared beam through a sample cell (containing $\mathrm{CO}$ or $\mathrm{CO}_{2}$ ) and measuring the amount of infrared absorbed by the sample at the necessary wavelength, a NDIR detector is able to measure the volumetric concentration of $\mathrm{CO}$ or $\mathrm{CO}_{2}$ in the sample. Smoke opacity was measured by AVL-437C smoke meter after reducing the pressure and temperature in the expansion chamber.

\subsection{Uncertainty analysis}

Uncertainty, the error of the experiment can occur due to the procedure, experiment condition, calibration as well as the environment. Defining uncertainty is vital in verifying the reliability of experiments. The percentage uncertainties of the experiment were calculated using the linearized approximation method and are \pm 4.35 . Measuring accuracy and uncertainty of various equipment are listed Tables 5, and Tables 6, 7 and 8 in "Appendix" show the sample calculation of uncertainties percentage for $\mathrm{HC}, \mathrm{CO}$ and $\mathrm{NO}_{x}$ emissions.
Uncertainty $=$ Square root of $[$ (uncertainty of

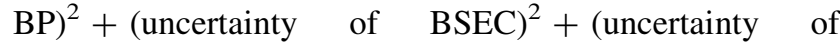
BTE $)^{2}+$ (uncertainty of $\left.\mathrm{NO}_{x}\right)^{2}+$ (uncertainty of

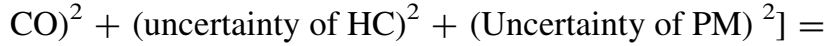

$$
\begin{aligned}
& \sqrt{\left[(0.75)^{2}+(1.8)^{2}+(1.45)^{2}+(0.45)^{2}+(1.1)^{2}+(2)^{2}+(1.9)^{2}\right]} \\
& \quad= \pm 4.35 \%
\end{aligned}
$$

\subsection{Test fuels conditions}

Fuel properties were tested for all the tested fuels as per ASTM standards. Engine speed was retained at $1300 \mathrm{rpm}$ during the trial. Errors during the measurement of $\mathrm{CO}, \mathrm{HC}$, $\mathrm{NO}_{x}$ and smoke emission were found by the procedure recommended by Moffat et al. (1985).

\section{Results and discussion}

\subsection{Carbon monoxide (CO)}

Variation in carbon monoxide emissions with a load for CNSBD1000, CNSBD900H100, and CNSBD800H200 is shown in Fig. 1. CO emissions from biofuels are comparatively less than diesel at all brake power. This is as a result of the abundant availability of inbuilt oxygen in hexanol and cashew shell biodiesel blends (Sahin and Aksu 2015). $\mathrm{CO}$ emission decreases with increase in hexanol content. By doping 100 and $200 \mathrm{~mL}$ of hexanol to CNSBD, 8.1\% and $9.3 \%$ of $\mathrm{CO}$ emissions were lowered, respectively. The reason for lower $\mathrm{CO}$ emissions for CNSBD900H100, CNSBD800H200 is because of improved combustion. Hexanol acts as additional oxygen buffer which stores and 
Table 5 Gas analyzer and smoke meter accuracy details

\begin{tabular}{lll}
\hline Parameters & Accuracy & Uncertainty, \% \\
\hline $\mathrm{CO}$ & $0.01 \%$ & \pm 1.1 \\
$\mathrm{HC}$ & $\pm 2 \mathrm{ppm}$ & $\pm \mathbf{2}$ \\
$\mathrm{NO}_{x}$ & $\pm 10 \mathrm{ppm}$ & \pm 0.45 \\
$\mathrm{Smoke}$ & $\pm 1 \%$ full-scale reading & \pm 1.9 \\
$\mathrm{BTE}$ & \pm 0.5 & \pm 1.45 \\
Brake-specific fuel consumption (BSFC) & $\pm 0.05 \mathrm{~g} / \mathrm{kWh}$ & \pm 1.8 \\
\hline
\end{tabular}

CO Carbon monoxide, $H C$ Hydrocarbon, $N O_{x}$ Nitrogen Oxide, BTE Brake Thermal Efficiency

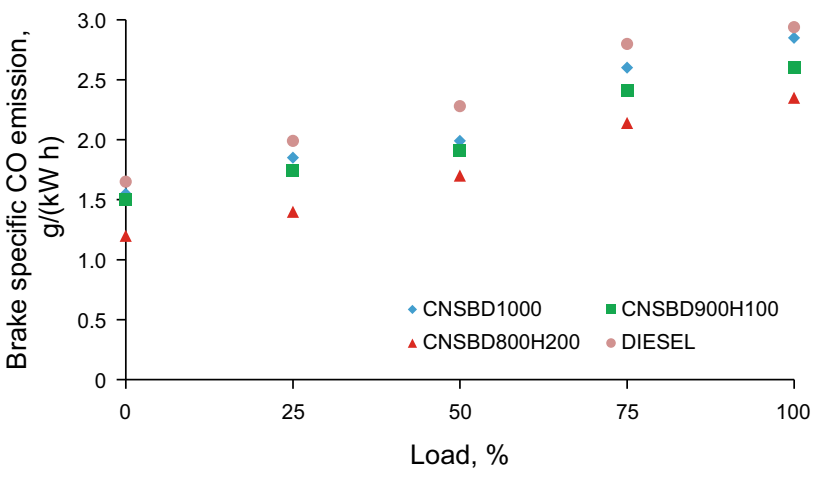

Fig. 1 Variation of $\mathrm{CO}$ with load

releases during combustion (De Poures et al. 2017). The other possible reason for the reduction of $\mathrm{CO}$ emissions is owing to reduced viscosity of CNSBD900H100, CNSBD800H200. The fuel with lesser viscosity aids a better evaporation of fuel with air and results in improved combustion \& lesser $\mathrm{CO}$ emissions. This result is in agreement with many other experimental works (Rajesh Kumar and Saravanan 2015; Aydin and Ogut 2017; Sundar and Saravanan 2011).

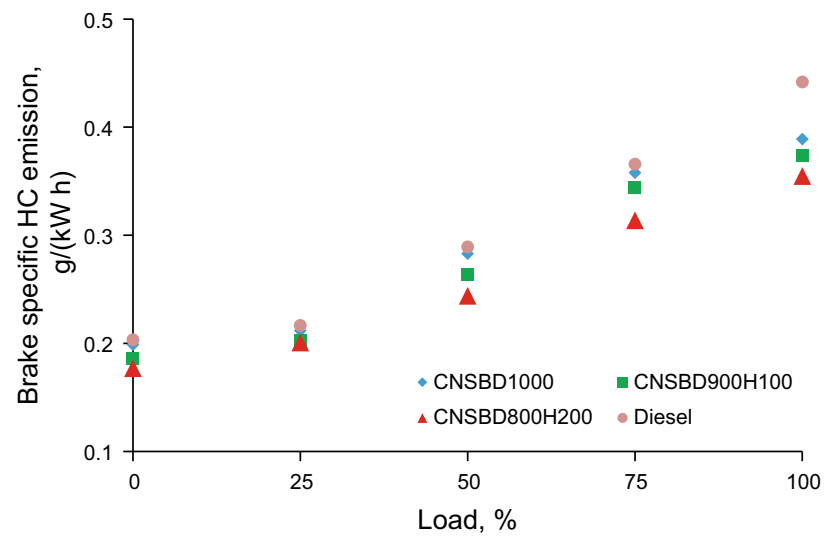

Fig. 2 Variation of $\mathrm{HC}$ with load

\subsection{Hydrocarbons (HC)}

Variation in hydrocarbon emissions with a load for CNSBD1000, CNSBD900H100, and CNSBD800H200 is shown in Fig. 2. HC emissions from hexanol and biodiesel blends were lower than diesel at all loads. This attributed to the excess oxygen present in the fuel (Yuvarajan and Venkata Ramanan 2016a).

$\mathrm{HC}$ emissions increased with load for all the fuels. At higher loads, the mixture was too rich causing incomplete combustion and higher HC emission (Devarajan et al. 2016). HC emissions drop at all brake power by doping with hexanol. Increasing the hexanol content reduces the $\mathrm{HC}$ emissions significantly. This was caused by the lower viscosity of CNSBD by doping hexanol (Devarajan et al. 2017). The viscosity of CNSBD900H100 and CNSBD800H200 was reduced by $1.6 \%$ and $1.8 \%$, respectively, comparing neat CNSBD. Due to lower viscosity, the mixing rate of fuel with air was drastically improved causing enhanced combustion and lower HC emission (Venkata Ramanan and Yuvarajan 2016). In addition, the vaporization of hexanol was faster which increased the pace of vaporization (De Poures et al. 2017; Sundar and Saravanan 2011).

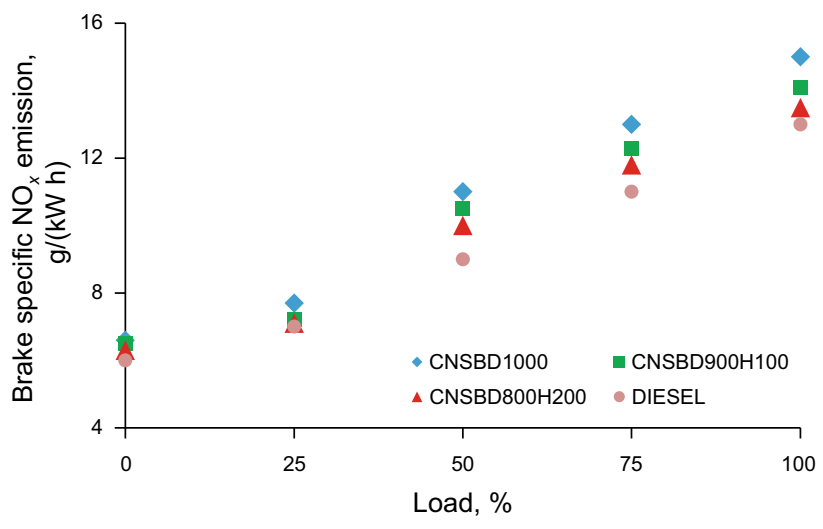

Fig. 3 Variation of $\mathrm{NO}_{x}$ with load 


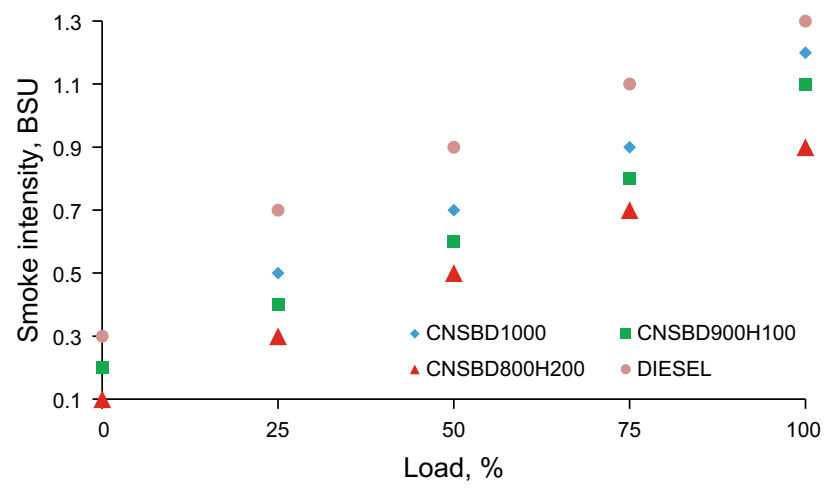

Fig. 4 Variation of smoke intensity with load

\subsection{Oxides of nitrogen (NOx)}

Variation in $\mathrm{NO}_{x}$ emissions with a load for CNSBD1000, CNSBD900H100, and CNSBD800H200 is shown in Fig. 3. $\mathrm{NO}_{x}$ emission of CNSBD, CNSBD900H100 and CNSBD800H200 was found to be higher than that of diesel at all brake power. Higher oxygen content in the alcohol and biodiesel blends was favorable to the combustion process and consequentially increased its temperature (Britto and Martins 2014; Yuvarajan and Venkata Ramanan 2016b).

$\mathrm{NO}_{x}$ emissions increase with a load for all test fuels. At higher loads, the temperature attained by the combustion chamber will be high causing higher $\mathrm{NO}_{x}$ emissions (Yuvarajan and Venkata Ramanan 2016c). Further, at higher loads, richer fuel mixture is supplied. By doping $10 \%$ and $20 \%$ of hexanol to CNSBD, the $\mathrm{NO}_{x}$ emissions were reduced by $3.1 \%$ and $4.7 \%$. This is because of lower cylinder temperature attained by these blends as a result of the higher latent heat of vaporization and lower calorific value of hexanol in CNSBD. Further, it is also due to reduced viscosity of the hexanol and biodiesel blends.

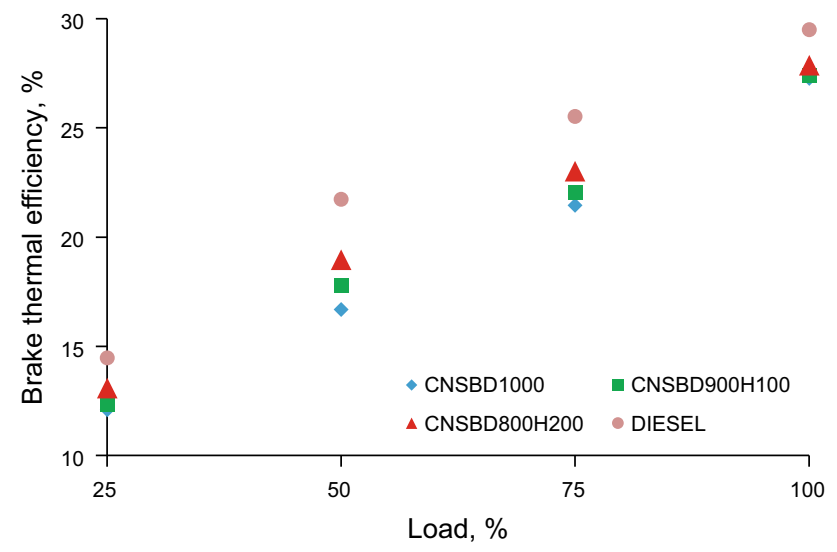

Fig. 5 Variation of brake thermal efficiency with load
Lower viscosity of CNSBD and hexanol blend aids better atomization of fuel droplets and generates higher dispersion rate leading to improved combustion rate (lower ignition delay) and thereby reducing the temperature in the combustion chamber (Sundar and Saravanan 2011; De Poures et al. 2017).

\subsection{Smoke emissions}

Variation in smoke emissions with a load for CNSBD1000, CNSBD900H100, and CNSBD800H200 is shown in Fig. 4. Smoke emissions for hexanol and cashew shell biodiesel blends are lower than diesel at all loads owing to inbuilt excess oxygen content in biofuels (Yuvarajan and Venkata Ramanan 2016c). Smoke emission increases with load for all fuels. At higher load, a higher measure of fuel is required to sustain the constant power output leading higher smoke emissions ( $\mathrm{Li}$ et al. 2015; Yilmaz and Atmanli 2017).

By doping $10 \%$ and $20 \%$ of hexanol to CNSBD, smoke emission was reduced by $1.1 \%$ and $1.4 \%$, respectively. This is caused by oxygen availability in hexanol which enhances the combustion rate and reduce formation of smoke emissions (Sundar and Saravanan 2011; De Poures et al. 2017).

\subsection{Brake thermal efficiency (BTE)}

Brake thermal efficiency defines the amount of useful energy obtained by burning a fuel. Variation in BTE with a load for CNSBD1000, CNSBD900H100, CNSBD800H200, and diesel is depicted in Fig. 5. The efficiency of diesel fuel was higher than CNSBD, CNSBD900H100, and CNSBD800H200 at all loads. This is as a result of the lower heating value of biodiesel and alcohol blends (De Poures et al. 2017). The efficiency of all fuels increases with load. At higher loads, the amount of fuel supplied to maintain power is more which consecutively results in higher BTE (Yuvarajan et al. 2017).

It was also found from the figure that the BTE for cashew nut shell biodiesel and hexanol blends (CNSBD900H100 and CNSBD800H200) increases with hexanol content. BTE for CNSBD900H100 and CNSBD800H200 was higher than CNSBD by $0.48 \%$ and $0.75 \%$, respectively, at full load conditions. The possible reason could be due to the higher energy density of hexanol which enhances the rate of combustion and ends up with higher BTE (Sundar and Saravanan 2011). Moreover, the viscosity of CNSBD900H100 and CNSBD800H200 was lower than CNSBD1000 causing improved atomization and vaporization of fuel with air leading to higher BTE (Rajesh Kumar and Saravanan 2015; Aydin and Ogut 2017; Sundar and Saravanan 2011). 


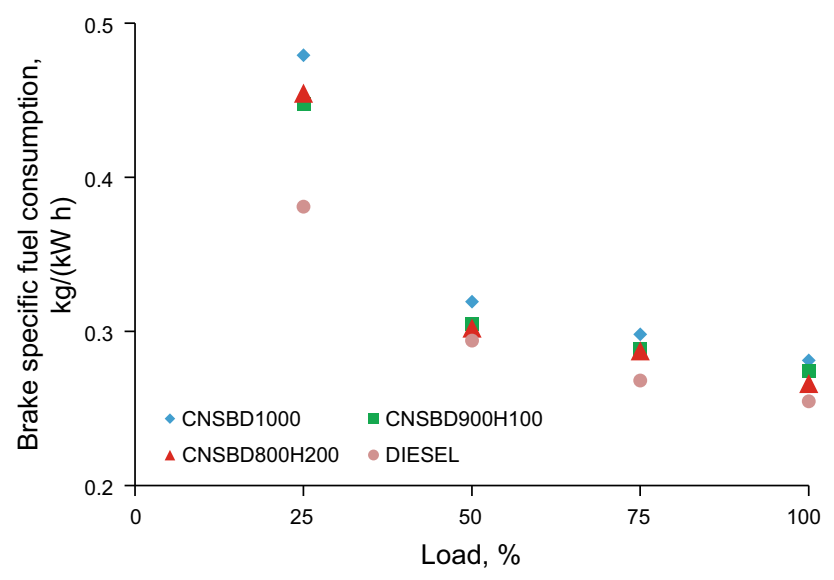

Fig. 6 Variation of brake-specific fuel consumption (BSFC) with load

\subsection{Brake-specific fuel consumption}

Brake-specific fuel consumption gives the quantity of fuel required to produce a unit of power output. Variation in brake-specific fuel consumption (BSFC) with a load for CNSBD1000, CNSBD900H100, CNSBD800H200 and diesel is shown in Fig. 6. BSFC increases with a load of all the tested fuel. At higher load, the fuel required to maintain the constant steady power output was higher (Yuvarajan and Venkata Ramanan 2016c). BSFC for diesel was lowest among all test fuels owing to its higher calorific value (Yilmaz and Atmanli 2017).

BSFC for CNSBD900H100 and CNSBD800H200 at full load condition was 0.00752 and $0.01484 \mathrm{~kg} / \mathrm{kWh}$ lower than CNSBD1000. BSFC reduces with an increase in hexanol content. This was due to increase in energy density of fuel mixtures by doping hexanol. In addition, it was also due to a reduction in viscosity of fuel with the addition of hexanol (Sundar and Saravanan 2011; De Poures et al. 2017). Fuel with lower viscosity assists the combustion process as it combines the fuel with air.

\section{Conclusion}

The impact of adding hexanol to cashew nut shell biodiesel on emission characteristics was measured and compared with petroleum diesel. The following were the observation derived from this experimental work:

(1) Hexanol was found to be miscible in cashew nut shell biodiesel.

(2) $\mathrm{CO}, \mathrm{HC}$, smoke emissions of hexanol and neat CNSBD blends were lower than diesel at all loads.

(3) CO emissions for CNSBD1000 drop by $8.1 \%$ and $9.3 \%$ when blending it with hexanol of $10 \%$ and $20 \%$ by volume.

(4) $\mathrm{HC}$ emissions were reduced by $1.6 \%$ and $1.8 \%$ for CNSBD/hexanol blends at all loads.

(5) $\mathrm{NO}_{x}$ emissions for CNSBD1000 were $4.71 \%$ higher than diesel at loads. However, by adding hexanol to CNSBD1000, $\mathrm{NO}_{x}$ emissions were reduced by $3.1 \%$ and $4.7 \%$ for at all loads.

(6) Smoke opacity reduced for CNSBD/hexanol blends by $1.1 \%$ and $1.4 \%$ when compared to neat CNSBD1000.

(7) BTE was found to increase marginally by adding CNSBD/hexanol blends. However, it is found lower than diesel at all loads.

(8) BSFC reduces with increase in the percentage of hexanol in CNSBD/hexanol blends.

Open Access This article is distributed under the terms of the Creative Commons Attribution 4.0 International License (http://creative commons.org/licenses/by/4.0/), which permits unrestricted use, distribution, and reproduction in any medium, provided you give appropriate credit to the original author(s) and the source, provide a link to the Creative Commons license, and indicate if changes were made.

\section{Appendix 1}

See Table 6.
Table 6 Average calculation of $\mathrm{HC}$ emission

\begin{tabular}{lllll}
\hline Engine load, \% & \multicolumn{3}{l}{$\left(\mathrm{HC}_{\mathrm{BD}}-\mathrm{HC}_{\mathrm{D}}\right) / \mathrm{HC}_{\mathrm{D}}$ for different fuels } \\
\cline { 2 - 5 } & CNSBD1000,\% & CNSBD900H100, \% & CNSBD800H200, \% & CNSBD700H300, \% \\
\hline 0 & -28.85 & -42.31 & -17.31 & -28.94 \\
25 & -23.75 & -40.00 & -31.25 & -36.75 \\
50 & -36.67 & -50.00 & -40.00 & -43.67 \\
75 & -28.57 & -48.57 & -34.29 & -42.86 \\
100 & -41.67 & -58.33 & -36.25 & -47.50 \\
Average & -31.90 & -47.84 & -31.82 & -39.94 \\
\hline
\end{tabular}

$H C_{B D} \mathrm{HC}$ emission of biodiesel-hexanol blends, $H C_{D} \mathrm{HC}$ emission of diesel 


\section{Appendix 2}

See Table 7.

Table 7 Average calculation of $\mathrm{CO}$ emission

\begin{tabular}{lllll}
\hline Engine load, \% & \multicolumn{3}{l}{$\left(\mathrm{CO}_{\mathrm{BD}}-\mathrm{CO}_{\mathrm{D}}\right) / \mathrm{CO}_{\mathrm{D}}$ for different fuels } \\
\cline { 2 - 5 } & $\mathrm{CNSBD} 1000, \%$ & $\mathrm{CNSBD} 900 \mathrm{H} 100, \%$ & $\mathrm{CNSBD} 800 \mathrm{H} 200, \%$ & $\mathrm{CNSBD} 700 \mathrm{H} 300, \%$ \\
\hline 0 & -10.82 & -19.52 & -6.14 & -8.15 \\
25 & -5.82 & -17.20 & -4.59 & -13.78 \\
50 & -25.18 & -36.03 & -13.54 & -20.16 \\
75 & -18.89 & -31.30 & -6.52 & -15.96 \\
100 & -19.33 & -61.73 & -6.67 & -40.00 \\
Average & -16.01 & -33.16 & -7.49 & -19.61 \\
\hline
\end{tabular}

$C O_{B D} \mathrm{CO}$ emission of biodiesel-hexanol blends, $C O_{D} \mathrm{CO}$ emission of diesel

\section{Appendix 3}

See Table 8 .

Table 8 Sample calculation of uncertainty $(\%)$

\begin{tabular}{lcccc}
\hline \multicolumn{2}{l}{$\mathrm{NO}_{x}$ emissions in three tests, $\mathrm{ppm}$} & & Average $\mathrm{NO}_{x}$ emissions $( \pm 1), \mathrm{ppm}$ & Uncertainty, \% \\
\hline Test 1 & Test 2 & Test 3 & & 0.55 \\
\hline 363 & 365 & 363 & 364 & 0.58 \\
523 & 521 & 519 & 521 & 0.43 \\
689 & 692 & 693 & 691 & 0.37 \\
808 & 808 & 812 & 810 & 0.33 \\
895 & 899 & 895 & 896 & 0.45 \\
\hline
\end{tabular}

\section{References}

Aydin F, Ogut H. Effects of using ethanol-biodiesel-diesel fuel in single cylinder diesel engine to engine performance and emissions. Renew Energy. 2017;103:688-94. https://doi.org/10. 1016/j.renene.2016.10.083.

Britto RF, Martins CA. Experimental analysis of a diesel engine operating in diesel-ethanol dual-fuel mode. Fuel. 2014;134:140-50. https://doi.org/10.1016/j.fuel.2014.05.010.

Campos-Fernandez J, Arnal JM, Gomez J, Lacalle N, Dorado MP. Performance tests of a diesel engine fueled with pentanol/diesel fuel blends. Fuel. 2013;107:866-72. https://doi.org/10.1016/j. fuel.2013.01.066.

De Poures MV, Sathiyagnanam AP, Rana D, Rajesh Kumar B, Saravanan S. 1-Hexanol as a sustainable biofuel in DI diesel engines and its effect on combustion and emissions under the influence of injection timing and exhaust gas recirculation (EGR). Appl Therm Eng. 2017;113:1505-13. https://doi.org/10. 1016/j.applthermaleng.2016.11.164.

Devarajan Y, Jayabal Kumar R, Ragupathy D, Venu H. Emissions analysis on second generation biodiesel. Front Environ Sci Eng. 2016. https://doi.org/10.1007/s11783-017-0891-0.

Devarajan Y, Munuswamy B, Nagappan B. Emissions analysis on diesel engine fueled with cashew nut shell biodiesel and pentanol blends. Environ Sci Pollut Res. 2017;24(14):13136-41. https:// doi.org/10.1007/s11356-017-8915-7.

Karabektas M, Hosoz M. Performance and emission characteristics of a diesel engine using isobutanol-diesel fuel blends. Renew Energy. 2009;34(6):1554-9. https://doi.org/10.1016/j.renene. 2008.11.003.

Li L, Wang J, Wang Z, Xiao J. Combustion and emission characteristics of diesel engine fueled with diesel/biodiesel/ pentanol fuel blends. Fuel. 2015;156:211-8. https://doi.org/10. 1016/j.fuel.2015.04.048.

Moffat RJ. Using uncertainty analysis in the planning of an experiment. J Fluid Eng. 1985;107(2):173. https://doi.org/10. $1115 / 1.3242452$.

Mohod AG, Khandetod YP, Powar AG. Processed cashew shell waste as fuel supplement for heat generation. Energy Sustain Dev. 2008;12(4):73-6. https://doi.org/10.1016/s0973-0826(09)600090.

Mohod A, Jain S, Powar A. Cashew nut shell waste: availability in small-scale cashew processing industries and its fuel properties for gasification. ISRN Renew Energy. 2011;2011:1-4. https:// doi.org/10.5402/2011/346191.

Mohod AG, Jain S, Khandetod YP. Potential assessment and characterization of cashew nut shells as fuel. J Biofuels 
Bioenergy. 2015;1(1):71. https://doi.org/10.5958/2454-8618. 2015.00009.7.

Murcak A, Hasimoglu C, Cevik I, Karabektas M, Ergen G. Effects of ethanol-diesel blends to performance of a DI diesel engine for different injection timings. Fuel. 2013;109:582-7. https://doi. org/10.1016/j.fuel.2013.03.014.

Murcak A, Hasimoglu C, Cevik I, Kahraman H. Effect of injection timing to performance of a diesel engine fueled with different diesel-ethanol mixtures. Fuel. 2015;153:569-77. https://doi.org/ 10.1016/j.fuel.2015.03.028.

Park SH, Youn IM, Lee CS. Influence of ethanol blends on the combustion performance and exhaust emission characteristics of a four-cylinder diesel engine at various engine loads and injection timings. Fuel. 2011;90(2):748-55. https://doi.org/10. 1016/j.fuel.2015.03.028.

Rajesh Kumar B, Saravanan S. Effect of exhaust gas recirculation (EGR) on performance and emissions of a constant speed DI diesel engine fueled with pentanol/diesel blends. Fuel. 2015;160:217-26. https://doi.org/10.1016/j.fuel.2015.07.089.

Rakopoulos CD, Dimaratos AM, Giakoumis EG, Rakopoulos DC. Investigating the emissions during acceleration of a turbocharged diesel engine operating with bio-diesel or n-butanol diesel fuel blends. Energy. 2010a;35(12):5173-84. https://doi.org/10.1016/ j.energy.2010.07.049.

Rakopoulos DC, Rakopoulos CD, Hountalas DT, Kakaras EC, Giakoumis EG, Papagiannakis RG. Investigation of the performance and emissions of bus engine operating on butanol/diesel fuel blends. Fuel. 2010b;89(10):2781-90. https://doi.org/10. 1016/j.fuel.2010.03.047.

Rakopoulos CD, Dimaratos AM, Giakoumis EG, Rakopoulos DC. Study of turbocharged diesel engine operation, pollutant emissions and combustion noise radiation during starting with biodiesel or n-butanol diesel fuel blends. Appl Energy.
2011;88(11):3905-16. https://doi.org/10.1016/j.apenergy.2011. 03.051 .

Sahin Z, Aksu ON. Experimental investigation of the effects of using low ratio n-butanol/diesel fuel blends on engine performance and exhaust emissions in a turbocharged DI diesel engine. Renew Energy. 2015;77:279-90. https://doi.org/10.1016/j.renene.2014. 11.093.

Sundar R, Saravanan G. Influence of hexanol-diesel blends on constant speed diesel engine. Therm Sci. 2011;15(4):1215-22. https://doi.org/10.2298/tsci101001110s.

Venkata Ramanan M, Yuvarajan D. Emission analysis on the influence of magnetite nanofluid on methyl ester in diesel engine. Atmos Pollut Res. 2016;7(3):477-81. https://doi.org/10. 1016/j.apr.2015.12.001.

Yilmaz N, Atmanli A. Experimental assessment of a diesel engine fueled with diesel-biodiesel-1-pentanol blends. Fuel. 2017;191:190-7. https://doi.org/10.1016/j.fuel.2016.11.065.

Yuvarajan D, Venkata Ramanan M. Investigation on effect of magnetite nanofluid on performance and emission patterns of methyl esters of bio diesel. J Environ Eng Landsc Manag. 2016a;24(2):90-6. https://doi.org/10.3846/16486897.2016.1142447.

Yuvarajan D, Venkata Ramanan M. Effect of magnetite ferrofluid on the performance and emissions characteristics of diesel engine using methyl esters of mustard oil. Arab J Sci Eng. 2016b;41(5):2023-30. https://doi.org/10.1007/s13369-016-2060-3.

Yuvarajan D, Venkata Ramanan M. Experimental analysis on neat mustard oil methyl ester subjected to ultrasonication and microwave irradiation in four stroke single cylinder diesel engine. J Mech Sci Technol. 2016c;30(1):437-46. https://doi. org/10.1007/s12206-015-1248-x.

Yuvarajan D, Nagappan BK, Munuswamy DB. Performance and emissions analysis on diesel engine fuelled with cashew nut shell biodiesel and pentanol blends. Korean J Chem Eng. 2017;34(4):0364-3. https://doi.org/10.1007/s11814-016-0364-3. 